\title{
Integration of the French Language Teacher-Trainees' Experiences of the Teaching Practice into the Course Quality Enhancement at One University in Lesotho
}

\author{
Itumeleng Mokhele \\ Faculty of Education, National University of Lesotho, P.O.Box 180, Roma, Lesotho
}

\begin{abstract}
The study focuses on integrating student-teachers' experiences of the teaching practice into the quality enhancement of the course on Curriculum and Teaching of French language at a university in Lesotho. It was noticed during the lesson observations that students' teachers who have registered for the course struggled to apply teaching methods learnt theoretically in practice. This called for immediate intervention in the form of research undertaking as the situation impacted on the quality of the course. Hence the investigation centres on "how does the integration of teacher -trainees' experiences of the teaching practice improve the quality of the course on curriculum and teaching of French language at the university?" was conducted. The nature of the study called for both qualitative and quantitative data, hence mixed methods approach is used. A structured questionnaire was used for data collection because the study sought both experiences, opinions on how the course could be improved as well as the aggregation of some responses. Fourth year students undertaking the course on curriculum and teaching of French language during the 2016/2017 academic year constituted the population for the case under study. Findings indicate that most student-teachers of French language found the teaching practice to be challenging. In conclusion the study shows that integrating student teachers' experiences of the teaching practice can contribute to the quality enhancement of the course under investigation.
\end{abstract}

Keywords: Integration, French language Teacher-trainees, Experiences, Course quality enhancement

DOI: $10.7176 / \mathrm{JEP} / 10-14-08$

Publication date:May $31^{\text {st }} 2019$

\section{Introduction}

Higher Education is vital to the existence of institutions of higher learning such as universities in any given country. Zhang (2010:86) maintains that quality in higher education is a multidimensional concept. As a result, it should embrace functions and activities as diverse as teaching and academic programmes, research and scholarship, staffing, students, buildings, facilities, equipment, community service and capacity building. In order to monitor the quality of education dispensed by such institutions, feedback from students about the internship programs that they undertake in different disciplines can contribute largely to enhancing the quality of courses offered. According to Raselimo (2013: 57) quality is determined by evaluating the extent to which institutional goals as stated in programmes objectives and missions are achieved. Therefore in order to evaluate the quality of various programmes in institutions of higher learning, it is necessary to begin at the individual program level and then extend the same principle at the department level. Within the departmental level, there shall be unit level where courses are found. However, Parveen (2012:489) argues that teacher education is one of the important branches of education because the development of future generations depends on the quality of teachers. Nonetheless, Komba and Kira (2013:157) in their study on the effectiveness of teaching practice in improving student teachers' skills, they found out that the duration spend for the internsip program was inadequate.

In this paper, the terms course and program are used interchangeably as the course is found within a particular program. Course quality enhancement is approached from the teaching practice perspective. Hence, Chennat (2014:79) cites (Ratsoy et al, 1987, 8) who states that the internship programs are supposed to facilitate "the transition from student status in a profession's pre-service education program to the status of the fully fledged member of the profession" The present study focuses on the Language and Social Education Department within the teacher training faculty of one university in Lesotho. The aim of the study is to assess the extent to which integrating teacher-trainees' feedback on the internship program contribute to quality enhancement of the course on curriculum and teaching of French language. Materu (2007) as cited by Raselimo contends that quality assurance is a planned, systematic process of reviewing an institution or programme to determine whether or not it satisfies the required standards. Despite varying rigidity in terms of adherence to quality standards by various programmes, student-teachers' feedback on their experiences on the teaching practice can contribute largely to monitoring the quality and the standards of courses offered vis-à-vis the market. Hence Hénard and Roseveare (2012) state that quality teaching in higher education matters for student learning outcomes. This is why it is important for institutions to ensure that the education they offer meets the expectations of students and the requirements of employers both today and for the future. 


\subsection{Objectives of the study:}

- To evaluate the course on curriculum and teaching of French language.

- To integrate the student-teacher's experience of the teaching practice into the quality enhancement of the course on curriculum and teaching of French language.

- To make the course responsive to needs of the teacher trainees who pursue it.

- To improve the quality of the course.

\subsection{Research Question}

How does the integration of the teacher trainees' experiences of the teaching practice improve on the quality of the course on Curriculum and Teaching of French language at one university in Lesotho?

\subsection{Research methodology:}

The mixed method approach has been used in this study as it allows for the combination of two methods of data collection. According to Saunders, Lewis and Thornhill (2016:169), mixed methods research is a branch of multiple methods that combines the use of quantitative and qualitative data collection techniques and analytical procedures. As a result, concurrent triangulation design has been used in this study. This refers to the collection of both qualitative and quantitative data in the same phase of research in order to compare how these data sets support one another (Saunders et al, 2016:170). Hence the case study of the fourth year students enrolled in the course on Curriculum and Teaching of French language has been developed. A structured open-ended questionnaire was used for data collection because the study sought both experiences and opinions on how the course can be improved. Numerical responses are aggregated. Students in the fourth year of course on Curriculum and Teaching of French language during the 2016/2017 academic year constituted the population for the case under study. Participants were eighteen students out of twenty five who were registered for the course. Both content analysis and simple statistical analysis are employed because the collected data comprises of both texts and figures that could be aggregated using basic and elementary statistics.

\section{Theoretical underpinnings}

This study draws on quality management theory because the aim of higher institutions such as universities is to offer programs of high quality as this will guarantee their sustainability and competitive advantage. According to Raising, Ericsson and Abdulovic (2011: 471), the quality paradigm is an essential part of business in the US as well as on a global scale today. They posit that it took a long time to recognize the pivotal role of quality management for organizational excellence. Raising et al further indicate that Total Quality Management (TQM) and most of its derivatives can be traced back to the period when the American quality pioneers developed quality management frameworks, taught them and supported their application in the Japanese automobile industry. The study that Raising et al conducted concluded that rather than implementing rigid quality framework, it is more important to have consistent and continuous quality approach. Hence the present paper seeks to enhance the course quality management through the use of student-teachers' feedback from the teaching practice. It is believed that their experiences have the bearing on course quality endeavours in the French unit of the Language and Social Education Department. On the other hand, Zhang (2010:86) argues that scholars previously defined quality of education by adopting the concept of quality that [sic] is used in management. According to the Education Dictionary as cited by Zhang, "the quality of education is the evaluation of educational level and effect". She further posits that the achievements in the quality of education will definitely come from the quality of the persons who are educated. In line with the preceding definition of quality in education, the effects that the teaching practice had on the student-teachers actually reflect on the quality of the course. This perspective can also be used as the framework for evaluating different courses within institutions of higher learning in Lesotho and elsewhere.

Internship programs reflect on the quality of programs offered by teacher-training institutions. Over the past years, internships have taken an increasingly important role in education, state Tackett et al (2001) as cited in Bukaliya (2012:118). They posit that internships provide students with many advantages such as gaining experience and obtaining career related direction, to networking with other students from various institutions. However, Monyatsi (2004:48) states that teaching practice as a form of internship aims to introduce prospective teachers to the real teaching situations and routines under the guidance of suitably qualified professionals. On the similar note, Bukaliya argues that institutions offering internship programs have equally benefitted through increased corporation and rapport with the industry. Not only in the past has internship been important, even in the present era it plays a decisive role in the teacher education program. This is because most of the content taught to student-teacher is theoretical hence there is a need for internship in order to grant them the opportunity to put into practice the content acquired mostly in the theoretically form. However, Heeradal and Bayaga (2011:1) contest that little attention has been given to the quality of pre-service teaching practice. They cite Huber et al (2005) who state that traditionally, all over the world, the quality of university faculties was judged 
using indicators such as entrance standards, reputation rankings and the presences of distinguished famous graduates. The aforementioned expectations were relatively skewed when it comes to education faculties across universities (Heeralal et al: 2011).

Furthermore, Furco (1996) as cited by Bukaliya defined internships as programs engaging students in service activities primarily with the purpose of providing them with hands on experience that enhances their learning and understanding of issues relevant to a particular area of study. Equally important, Bukaliya also cited McMahon and Quinn (1995) who described the same concept as supervised work experiences whereby students leave their institutions and get engaged in work related programs during which they are closely supervised by experienced job incumbents. Nonetheless, Jain and Parihar (2017: 59) insist "when student teachers begin their career with a high self efficiency on classroom instruction and using teaching methods, teaching aids, they are more concerned, ambitious for their task and work harder",

The preceding citation illustrates the importance of the theoretical components of the student- teacher training as it has a great bearing on their performance during the teaching practice.

However, for the purpose of the present study, internship is defined as the short-term engagement of students from institutions of higher learning to practice what they have learnt theoretically in real life situations. However, it must be noted that the form (length) of the teaching practice varies from one institution to another. This is confirmed by Perry as cited by Kiggundu and Nayimuli (2009) who posit that teaching practice can be conducted in a number of forms depending on the institutions. They further indicate that some institutions send student teachers to go for teaching practice once a day each week while others do this over a semester while others send students in a two-to six weeks blocks. Similarly, Parveen (2012:488) states that placement for internship can be for two months to one year.

Moreover, Furco (1996), Lam and Ching, (2007) as quoted by Bukaliya, argue that internships help the trainee to bridge the gap between the academic learning process and the practical reality. Similarly (Beard, 1998) in Bukaliya (2012:122) posits that internship program contributes significantly towards enhancing knowledge base and motivational level of students. In addition, Kiggundu et al (2009:345) cite Marais \& Meier (2004:221) who insist that teaching practice as a form of internship represents a range of experiences to which studentteachers are exposed [to] when they work in classrooms and schools. They further contend that teaching practice is a challenging but important part of teacher training, especially in developing countries.

According to Chennat (2014:79), the research literature suggests that content mastery of teachers in their respective disciplines and their expertise in the way they transact this content knowledge to their students is one of the most important factors influencing student learning. He further posits that research indicates that the task of teaching is becoming increasingly complex; as a result, highly competent teachers apply a range of practices for varying purposes. They incorporate and integrate different kinds of knowledge, build up a sophisticated pedagogical repertoire and adapt to learner diversity while also shift contextual forces. Hence Ondigi (2011:96) quotes Brickman (1997) who argues thus

"the German universities developed a world reputation of seriousness in research and originality in methodologies of instruction and scholarship based on the free pursuit of scientific truth and the unconditional selection of teaching processes and materials by the faculty."

Schools where students-teachers of French language were placed questioned the quality of the product that the institution produces. However, Mpairwe (2010) states that several studies that have been done elsewhere have also indicated and concluded that a gap really exists between the quality of graduates produced and what the market demands (Bukaliya, 2012:113). According to Bukaliya, it is for this and other reasons that training institutions and employers have accepted the need to seek mitigating steps to bridge the gap.

Bukaliya argues that despite good intentions behind internship programs, interns on the field attachment have faced serious challenges among which are insufficient time and lack of funding for the program. He has conducted a quantitative study to establish the benefits and challenges faced by students' interns at the Zimbabwe Open University (2012:118). His study focused on the Faculty of Science and Technology and that of Social Science as most of the students on internship were from these two faculties. The results showed that the majority of the students preferred the attachment program because it exposed them to real life expectations of the world of work. Nonetheless, he indicates that the program faced a number of challenges that militated its effectiveness. Challenges included full time employees who were reluctant to disclose important information to students.

Lastly, Kagoda and Itagaar (2013:43) evaluated the kind of education that is received in teacher training colleges in Uganda. Their study slightly informed the present paper on methodological grounds as it used the qualitative approach and open-ended questionnaires. They insisted on this methodological approach because they were mainly interested in teacher trainees' perceptions, experiences and their assessment of the teacher education program in the school of education at Makerere University. In as much as Kagoda et al look do not specifically into the quality issues of neither the program nor the courses; they attempted to establish what teacher trainees 
feel needed to be improved in the education program offered by the institution under study.

\section{Results and discussions}

Results presented and discussed in this part are the outcome of the data collected using the structured open ended questionnaire which was administered to eighteen student-teachers who enrolled in the program on Curriculum and Teaching of French language. This questionnaire was self administered in order to give respondents adequate time to reflect on questions and answers they provided. Content analysis is used on items that sought for textual responses whereas tables are also employed to aggregate responses that merit such presentation. Eighteen items were presented to the respondent where some were closed while others were open.

Table 3.1: How did you find the teaching of French language during your internship?

\begin{tabular}{|l|l|}
\hline Responses & Number of respondents \\
\hline challenging & 5 \\
\hline Interesting \& challenging & 2 \\
\hline Quite challenging & 1 \\
\hline Interesting \& educative & 2 \\
\hline Great experience & 1 \\
\hline Quite interesting & 1 \\
\hline Fine but challenging & 1 \\
\hline Fun \& helpful & 1 \\
\hline Not too good & 2 \\
\hline Hard & 1 \\
\hline Ok \& a bit stressful & 1 \\
\hline Total & 18 \\
\hline
\end{tabular}

Teacher-trainees of French language have different experiences about the teaching of French language during their internship program. Their responses vary from challenging, quite challenging, interesting, interesting and educative, fun and helpful while some found it to be hard and a bit stressful.

The range of responses obtained in table 3.1 above reveals the complexity of teaching and how the teachertrainees found it. For the five student-teachers that found the teaching of French to be challenging, they state that learners were clueless about French language as most of them were complete beginners with the language. Besides, learners expected the training teachers to know everything. As for two respondents that found the teaching of French language to be interesting and challenging at the same time, the first indicates that it triggered him to know more about the language as well as its culture while the second states that it was a platform to unleash what he has learnt even though he had to face learners for the first-time.

For those that found it to be interesting, fun and helpful, very good and quite interesting, their reasons range from getting the opportunity to speak French language more often, the supportive and cooperative teachers, learnt more on how to be the best teacher, used the teaching aids that attracted learners' attention.

On the other hand, reasons for those that had negative experiences are as follows; one did not have the mentor who knew French language, the other says that student had negative attitude towards the subject while the some indicates that being in front of so many eyes for the first time and speaking such a scarce language was never interesting .

From the above responses, it can be seen that teaching practice of French language presented a plethora of experiences to individual teacher-trainees. Some liked the idea of using the language often while one found it to be intolerable. Some appreciated the challenge while others found factors such as learners "attitudes, lack of teaching and learning resources" to be daunting. Again, this item addresses objective one of this study as student-teachers' experiences permit course instructor to review the support framework given to students before and during the teaching practice. This also shows that integrating student-teachers' experiences of the teaching practice can help course designer to evaluate whether the teaching environment is enabling to students because some respondents state that they were speaking French language often. In this manner, the course on Curriculum and Teaching of French can be improved to cater for the meaningful experiences that student-teachers had while there were in the field, thus enhancing the quality of the course through allocating more lessons to speaking so that it does not annoy students during their practice for they would have been given adequate opportunity to practice the language and to be at ease with it.

Table 3.2: How long was internship program?

\begin{tabular}{|l|l|l|l|l|l|l|l|l|l|l|l|l|l|l|l|l|l|l|}
\hline Respondent & 1 & 2 & 3 & 4 & 5 & 6 & 7 & 8 & 9 & 10 & 11 & 12 & 13 & 14 & 15 & 16 & 17 & 18 \\
\hline $\begin{array}{l}\text { Duration } \\
\text { (weeks) }\end{array}$ & 10 & 10 & - & - & - & 16 & - & 12 & 12 & 12 & 12 & 12 & 12 & 10 & 11 & 10 & 10 & 10 \\
\hline
\end{tabular}

The responses indicate that the internship takes roughly two to three months as it is highlighted by six respondents who said that it lasted for 12 and 10 weeks respectively. The same number posits that the teaching 
practice lasted for 3 months whereas four respondents did not answer. On the other hand, one teacher-trainee states that the internship runs for eleven weeks while another one points that it takes four months.

From the information depicted above, it is clear that there is no fixed duration for the running of the internship program. Teacher-trainees who participated in this exercise seem to have undergone various durations yet they were under the similar teaching practice program. The only difference was the courses which they were teaching. However, the results show that the internship program runs approximately for two months and a half.

Table 3.3: Was the duration of the teaching practice adequate?

\begin{tabular}{|l|l|l|}
\hline Response & Respondent & Total \\
\hline Yes & 1 & 1 \\
\hline No & 17 & 17 \\
\hline Total & 18 & 18 \\
\hline
\end{tabular}

The above information reveals that the duration of the teaching practice is not enough because the majority of the teacher-trainees indicate that the time given for the internship is not adequate.

Table 3.4: Explanation on the duration of the teaching practice

\begin{tabular}{|l|l|}
\hline Frequency & Explanation \\
\hline 2 & $\begin{array}{l}\text { Progress was slow with complete beginners who are not keen to learn the subject. Besides, learners } \\
\text { need time to cope and understand the learning of French while also eliminating the negative attitude } \\
\text { through motivation. }\end{array}$ \\
\hline 6 & $\begin{array}{l}\text { Student teachers were only getting used to the teaching and they were beginning to discover } \\
\text { strategies that work for them and learners. }\end{array}$ \\
\hline 1 & $\begin{array}{l}\text { The student teachers like to be exposed to more complex content other than basics that are } \\
\text { introduced to beginners. }\end{array}$ \\
\hline 4 & $\begin{array}{l}\text { They felt that they are not yet perfect. One cannot get enough experience in just three months. } \\
\text { Admitting that there was some learning that took place but time was not enough. }\end{array}$ \\
\hline 1 & $\begin{array}{l}\text { There were some aspects that had to be worked on with little experience. } \\
\text { Fhe respondent found it interesting to teach learners as they were now able to speak and write }\end{array}$ \\
\hline 1 & Felt like he has learnt nothing. \\
\hline 2 & $\begin{array}{l}\text { They only taught once per week and did not get enough experience as they were not teaching every } \\
\text { day. }\end{array}$ \\
\hline
\end{tabular}

From the table 3.4 above, it is clear that student-teachers go to the teaching practice with very high expectations such as gaining the perfect experience. Nonetheless, the reality in schools is far different from their aspirations and ambitions hence a number of them felt like they did not learn anything.

From the given explanation, the program in the Curriculum and Teaching of French should be designed such that it gives students hands-on experience through practice based teaching. By so-doing, students' teachers would be prepared for the real life scenarios in schools by the time they go for their teaching practice exercise.

Table 3.5: Challenges that student-teacher encountered during the teaching practice

\begin{tabular}{|l|l|}
\hline Challenge & Frequency \\
\hline Lack of content & 2 \\
\hline Poor preparation & 10 \\
\hline Institutional challenges & 7 \\
\hline Personal & 4 \\
\hline Others & 8 \\
\hline
\end{tabular}


Figure 3.1: Challenges met during teaching practice

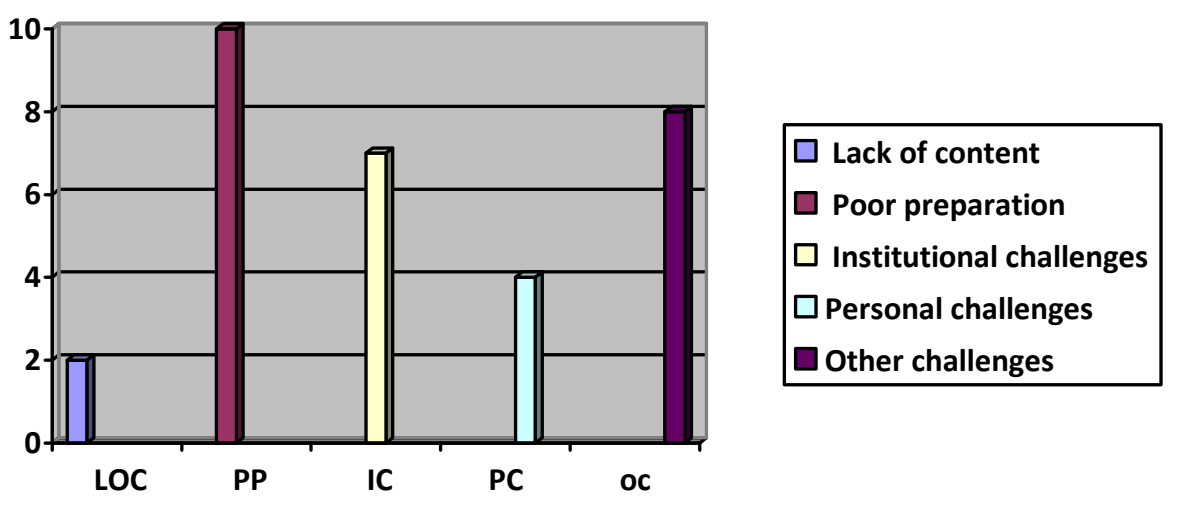

Figure 3.1 above shows poor preparation to be the biggest challenge that student teachers faced during the teaching practice. This was followed by other challenges which included time management, lack of material, language barrier, many students, student negative attitude and communication problems with tutors. Institutional challenges also manifested to be amongst the prominent challenges faced by student teachers.

Table 3.6: Explanations of challenges

\begin{tabular}{|l|l|}
\hline $\begin{array}{l}\text { Frequency } \\
\text { explanation }\end{array}$ & of \\
\hline 1 & -Learners only responded positively to traditional methods of teaching. \\
\hline 1 & $\begin{array}{l}\text {-Teaching methods advised did not enhance learning. } \\
\text {-It was difficult to introduce new concepts to learners because they would tell the student- } \\
\text { teacher how their former (original) taught them. }\end{array}$ \\
\hline 1 & Prepared too much content for one lesson. \\
\hline 1 & Go to class prepared but end up teaching something else. \\
\hline 4 & $\begin{array}{l}\text {-Mentors of student-teachers are always busy hence interns had to sort themselves out. } \\
\text {-at the beginning of the internship, interns did not know how to prepare and had too many } \\
\text { classes to prepare for. }\end{array}$ \\
\hline 3 & -Poor preparation due to lack of experience. \\
\hline 4 & - No books and any language laboratory. \\
\hline 1 & -Poor time management which led to preparation of more content or less. \\
\hline 1 & -Poor communication with tutors. \\
\hline 1 & -Learners lacked motivation. \\
\hline
\end{tabular}

From the above information, it can be seen that student-teachers go to the teaching practice with relaxed and over ambitious. As it could be seen, four students state that at the beginning they did not know how to prepare and there were many classes to prepare for. Moreover, mentor teachers were also busy to assist them. This send a different message as it can be seen that apart from getting the hands on teaching experience, studentteachers faces a number of challenges which some could be addressed through enhancing the quality of course in the manner that caters for some of challenges experienced.

Table 3.7: Teaching method used mostly by student-teachers

\begin{tabular}{|l|l|}
\hline Teaching method & Frequency \\
\hline Traditional method & 13 \\
\hline Direct method & 3 \\
\hline Audio-Oral method & 2 \\
\hline Audio-visual method & 0 \\
\hline Communicative approach & 8 \\
\hline Action approach & 2 \\
\hline
\end{tabular}

The traditional method was used mostly by student-teachers because out of 18 respondents, 13 of them opted to use this method. The other five respondents have used this teaching method in conjunction with the communicative approach. Out of this five, two respondents have also added the action approach. This says that seven student-teachers solely based their lessons on the traditional method of teaching French. As for the three that used direct method, two coupled it with the communicative approach whereas only two respondents out of eight based their lessons on the communicative approach. 


\section{Choice of teaching method}

There are various reasons that led the student teachers to choose the methods that they used in teaching French during their internship program. However, for the majority that resorted to the traditional method, it seems like they were looking for an easier way to teacher French language because some of their reasons include: looking for easier way to communicate to learners. On the other hand, for those who used communicative approach indicate that it is learner centred, interactive and it is envisaged by the French syllabus.

From the choice of methods used to teach French language, the results show that the majority that opted for the traditional method used it as an excuse not to use the target language. It is clear that most of the teaching was conducted using the learners' maternal language. As for the few that have explored other teaching methods, particularly the communicative approach, have used it for the practical reasons of making the teaching exercise to be learner-centred.

With regard to the choice of teaching methods, student-teachers were not able to link the methods learnt theoretically to the real life classroom situations. The traditional method of teaching languages was used primarily in the $18^{\text {th }}$ century to teach dead languages such as Latin, Greek and Roman. Therefore it is obsolete for the $21^{\text {st }}$ century student-teacher to use this method exclusively for teaching a living language like French. This factor also demonstrates brittle analytic skills from the teacher trainees as they were not able to closely assess the relevance of the teaching method before putting it into practice.

Table 3.8: Rating of teaching in terms of content, teaching method, interaction and classroom management

\begin{tabular}{|l|l|l|l|l|l|l|}
\hline Ratings/variables & Excellent & Good & Satisfactory & Average & Poor & Total \\
\hline Content & 6 & 8 & 3 & 0 & 1 & 18 \\
\hline Teaching Methods & 3 & 4 & 8 & 3 & 0 & 18 \\
\hline Interaction & 10 & 6 & 0 & 1 & 1 & 18 \\
\hline Classroom management & 7 & 4 & 1 & 5 & 1 & 18 \\
\hline
\end{tabular}

From table 3.8 above, it can be seen that interaction obtained the highest ranking with ten respondents who said that this variable was excellent. This was followed by the content and teaching methods which are selected by eight participants. The first variable is rated good whereas the last one is satisfactory. Classroom management was also selected by seven participants and it obtained excellent. This was followed by interaction with six respondents.

Table 3.9: Explanations for various ratings

\begin{tabular}{|c|c|c|}
\hline Variable & Rating & Explanation \\
\hline \multirow[t]{5}{*}{ Content } & Excellent & $\begin{array}{l}\text { - Learners did not study their notes. } \\
\text { - Student-teacher knew what was supposed to be delivered, when and how. } \\
\text { - Respondent was able to explain each topic to students without being } \\
\text { - } \text { stuck. } \\
\text { - } \text { Abood preparation at most time lead to the delivery of the right content.(2) } \\
\text { - }\end{array}$ \\
\hline & Good & $\begin{array}{l}\text { - Had enough for class. } \\
\text { - Was able to meet the objective and deliver content. } \\
\text { - } \quad \text { Through students' performance. } \\
\text { - } \quad \text { Although there were difficulties, correct content was used. } \\
\text { - } \quad \text { Good as the point was driven home in most lessons. } \\
\text { - } \quad \text { Always delivered right content. } \\
\text { - } \quad \text { Researched enough for lessons. } \\
\text { - } \quad \text { Failure to fully classify contents of content. }\end{array}$ \\
\hline & Satisfactory & $\begin{array}{ll}\text { - } & \text { Had enough for class. } \\
\text { - } & \text { Not allowed to use le guide pédagogique. } \\
\end{array}$ \\
\hline & Average & \\
\hline & Poor & - $\quad$ Taught using Et Toi only. \\
\hline \multirow[t]{2}{*}{$\begin{array}{l}\text { Teaching } \\
\text { methods }\end{array}$} & Excellent & $\begin{array}{l}\text { - } \quad \text { It suited students' learning style. } \\
\text { - } \quad \text { Able to achieve lesson objectives (2). }\end{array}$ \\
\hline & Good & $\begin{array}{l}\text { - It was not easy using one or two methods. } \\
\text { - Good as the ones that were used were mastered, however, there was a } \\
\text { desire to use more. } \\
\text { - Used best teaching methods for foreign languages. } \\
\text { - } \quad \text { Always considered the methods of teaching to use. }\end{array}$ \\
\hline
\end{tabular}




\begin{tabular}{|c|c|c|}
\hline Variable & Rating & Explanation \\
\hline & Satisfactory & $\begin{array}{l}\text { - It seemed to address learners' needs and allowed them to search for } \\
\text { information themselves. } \\
\text { - Used the method which is less recommended. } \\
\text { - Was able to use methods that allowed class to be effective. } \\
\text { - Helped the teaching to be effective. } \\
\text { - Sessons went well. } \\
\text { - Was able to achieve lesson objectives. } \\
\text { - Chose according to the type of student the respondent had. }\end{array}$ \\
\hline & Average & $\begin{array}{l}\text { - } \text { It was hard to get learners to interact as they would not read the books. } \\
\text { - } \quad \text { Struggled to understand how things worked. } \\
\text { - } \quad \text { Was able to use teaching methods appropriately. }\end{array}$ \\
\hline & Poor & \\
\hline \multirow[t]{5}{*}{ Interaction } & Excellent & $\begin{array}{l}\text { - } \text { Classroom atmosphere was very good and called for excellent } \\
\text { participation. } \\
\text { - } \text { Always engaged all learners in class. } \\
\text { - Was able to interact with learners. } \\
\text { - } \text { Students were energetic and persistence to learn every topic taught. } \\
\text { - } \quad \text { Talked with children and was approachable at all times. } \\
\text { - } \quad \text { Allowed learners to ask anytime and knew their weaknesses (2). }\end{array}$ \\
\hline & Good & $\begin{array}{l}\text { - Got along very well with learners and they were free to ask. } \\
\text { - Was engaging every learner. } \\
\text { - Was able to see absent-mindedness learners in class. } \\
\text { - After the introduction of some concepts, learners were able to } \\
\text { communicate } \\
\text { - Learners were very active in class most of the time. } \\
\text { - Was able to interact with learners. }\end{array}$ \\
\hline & Satisfactory & \\
\hline & Average & - $\quad$ Sometimes interaction was limited. \\
\hline & Poor & - $\quad$ Learners did not participate much and sometimes they were forced to talk. \\
\hline \multirow[t]{5}{*}{ Classroom } & Excellent & $\begin{array}{l}\text { - } \quad \text { Learners were usually attentive. } \\
\text { - Class always in order (2). } \\
\text { - Class frequently managed and environmentally friendly. } \\
\text { - Was excellent as the respondent always had authority. } \\
\text { - It was easy for learners to listen to the student-teacher as she was open to } \\
\text { them. } \\
\text { - Student concentrated in class. }\end{array}$ \\
\hline & Good & $\begin{array}{l}\text { - } \quad \text { Students behaved well in class. } \\
\text { - } \quad \text { Struggled to improve. } \\
\text { - } \quad \text { Able to move around to ensure participation by all learners. } \\
\text { - } \quad \text { Most learners were observant during the lesson except for few. }\end{array}$ \\
\hline & Satisfactory & $\begin{array}{l}\text { - Was able to manage learners even though sometimes they made noise in } \\
\text { groups. }\end{array}$ \\
\hline & Average & \\
\hline & Poor & - $\quad$ Did not have control over some students as there were many. \\
\hline
\end{tabular}

From the explanations above, it is clear that student- teachers had diverse reasons for their ratings of the four variables which were content, teaching methods, interaction and classroom management. Most variables were rated between excellent and good. However, the teaching method was largely rated as satisfactory as student-teachers seemed to know why they made choices to use some teaching methods over the others. 
Table 3.10: Language used mostly in teaching French language

\begin{tabular}{|l|l|l|}
\hline Language & Frequency & Total \\
\hline English & 13 & 13 \\
\hline Sesotho & 3 & 3 \\
\hline French & 3 & 3 \\
\hline Total & 18 & 18 \\
\hline
\end{tabular}

Out of eighteen respondents, thirteen used English language exclusively to teach French language. One has used both English and Sesotho language whereas two have only used Sesotho language to teach French, which is a foreign language to learners in Lesotho secondary schools. Lastly, only three student-teachers have used French language to teach French.

The information above send the warning lights to the institution that train French teachers in Lesotho particularly the French section of the Language and Social Education Department as the actions of studentteachers reflect on this particular section. The results further justifies the importance of integrating studentteachers' experiences into the program as this informs the course instructor on some of the practices that happens in French classrooms during the teaching practice. This is because teaching French language using learners' maternal language raises concerns over the quality of French language teacher-trainees produced by the unit of the department.

Table 3.11: Reasons for language choice of student-teachers

\begin{tabular}{|c|c|c|}
\hline $\begin{array}{l}\text { Number of } \\
\text { respondents }\end{array}$ & Language used & Reasons for using a chosen language \\
\hline 12 & English & $\begin{array}{l}\text {-It was easier to communicate with learners in order to make them } \\
\text { understand the requirements of the lesson. (1) } \\
\text {-The respondent was teaching complete beginners so she felt that using } \\
\text { French as a language of instruction would be inappropriate.(3) } \\
\text {-learners could hardly hear French.(5),(13) } \\
\text {-use English to translate as learners had little French. (6) } \\
\text {-Learners understand better and easily when communication is in English. } \\
\text { (7) } \\
\text {-Learners were complete beginners so the student-teacher understand.(8) } \\
\text {-Respondent taught in English to make learners grasp and understand.(10) } \\
\text {-the respondent taught junior classes so she had to switch English.(12) } \\
\text { - It wasn't easy to teach Form A(s) in French only. (14) } \\
\text {-Learners did not understand when instructions were given in French even } \\
\text { when gestures were used.(15) } \\
\text {-The more French was used, learners seemed bored and confused.(17) }\end{array}$ \\
\hline 2 & Sesotho & $\begin{array}{l}\text {-The use of Sesotho made learners participate. (1) } \\
\text {-Learners did not understand English very well. (18) }\end{array}$ \\
\hline 1 & English \&Sesotho & -Learners could understand both languages. (4) \\
\hline 3 & French & $\begin{array}{l}\text {-Respondent gave instructions in French. (9), (11) } \\
\text {-the responded wanted to give learners the opportunity to use French } \\
\text { language during French lessons. }\end{array}$ \\
\hline
\end{tabular}

As it can be observed from Table 3.11 above, student-teachers have various reasons for using English, Sesotho and French to teach French language in Lesotho secondary schools. As most of the reasons are intuitive, they do not comply with the teaching of French as a foreign language. Rather than using the learners' second language, teachers are encouraged to use learners' maternal language.

The picture depicted in this table reveals the vague future for the teaching of French language in Lesotho secondary schools. In particular, this put into question the nature and the quality of the course on teaching French at the university. Few learners who were taught by three students' teachers who used French language in their lessons were able to learn the language whereas the majority were taught either their maternal or their second language under false pretext of learning French language. 
Table 3.12: Skills acquired by learners taught by student-teachers

\begin{tabular}{|c|c|c|c|}
\hline $\begin{array}{l}\text { Frequency of } \\
\text { response }\end{array}$ & Skilled acquired & Explanation & Teaching method used \\
\hline 2 & Confidence & $\begin{array}{l}\text {-Learners were told that the first } \\
\text { step to learning is making } \\
\text { mistakes. } \\
\text {-learners felt free to speak and } \\
\text { answer in class even if the answer } \\
\text { is wrong. }\end{array}$ & -Traditional method \\
\hline 2 & Communication skills & $\begin{array}{l}\text {-No explanation } \\
\text {-Presentations were the teachers' } \\
\text { priority and learners had to } \\
\text { respond to questions using French } \\
\text { language }\end{array}$ & $\begin{array}{l}\text {-Traditional method, } \\
\text { communicative approach \& } \\
\text { action approach } \\
\text {-Traditional method, Audio- } \\
\text { oral method }\end{array}$ \\
\hline 3 & Listening \& speaking & $\begin{array}{l}\text {-Respondents always played } \\
\text { French songs before teaching. }\end{array}$ & $\begin{array}{l}\text {-Traditional Method \& } \\
\text { communicative approach } \\
\text { (used by 2respondents) } \\
\text {-Direct methods }\end{array}$ \\
\hline 3 & Writing \& speaking & $\begin{array}{l}\text {-Learners were asked to write and } \\
\text { repeat after the student-teacher. }\end{array}$ & $\begin{array}{l}\text {-Traditional } \\
\text {-Traditional, Audio-oral, } \\
\text { action\& communicative } \\
\text { approach } \\
\text {-Direct method }\end{array}$ \\
\hline 1 & Oral skills & $\begin{array}{l}\text {-Learners got to hear what was } \\
\text { said even if they cannot write it } \\
\text { down. }\end{array}$ & $\begin{array}{l}\text {-Traditional \& action } \\
\text { approach }\end{array}$ \\
\hline 1 & $\begin{array}{lr}\text { Reading, } & \text { Writing, } \\
\text { interpreting } & \text { French } \\
\text { \&speaking } & \\
\end{array}$ & $\begin{array}{l}\text {-Learners always practiced all the } \\
\text { mentioned skills and seemed to } \\
\text { excel. }\end{array}$ & -Traditional \\
\hline 1 & $\begin{array}{l}\text { Reading, note taking, } \\
\text { writing, listening }\end{array}$ & No explanation & -Communicative approach \\
\hline 1 & Presentation \& writing & No explanation & -Traditional \\
\hline 1 & $\begin{array}{l}\text { Reading, listening \& how } \\
\text { to approach other people \& } \\
\text { life in general }\end{array}$ & No explanation & -Communicative approach \\
\hline 1 & $\begin{array}{lll}\text { Reading, } \\
\text { speaking }\end{array}$ listening \& & $\begin{array}{l}\text { New sentences were constructed } \\
\text { daily using new words learners } \\
\text { brought. }\end{array}$ & -Traditional \\
\hline 1 & $\begin{array}{l}\text { Writing, listening } \quad \& \\
\text { speaking }\end{array}$ & $\begin{array}{l}\text {-Student teacher used mostly } \\
\text { audios. }\end{array}$ & Traditional \\
\hline 1 & Speaking & No explanation & Traditional \\
\hline
\end{tabular}

Table 3.12 reveals that most skills learners acquired in their respective schools where student-teachers were attached were more or less similar as they constitute the communication skills. However, the four competences of language learning which are listening, speaking, reading and writing appears often in the list. Speaking is the most frequent as it appears six times. It is followed by listening with five. Both reading and writing appeared four times each. With these basic skills in language learning, confidence and social skills were also imparted to learners as one respondent indicated that learners learnt how to approach other people and life in general. The latter point is significant to the improving the quality of the course on Curriculum and Teaching of French Language as the course instructor need to integrate life skills and interpersonal skills in student-teachers' curriculum because they may not think it is important to include it in their teaching practice.

Table 3.13: Reasons for choosing to teach French

\begin{tabular}{|l|l|}
\hline Frequency & Reasons \\
\hline 6 & For Job opportunities \\
\hline 10 & Love French language and language learning \\
\hline 2 & Like learning new things so French gave the challenge as it was a new language to respondents. \\
\hline
\end{tabular}

Table3.13 above shows that student-teachers specialising in French have chosen French language for various reasons which range from economic, social and status. Ten of eighteen respondents chose to study French language because they love the language. The other six chose it in order to secure job opportunities while 
the last two said that they like challenge therefore French language as the new subject to them, it really challenged them. The preceding results reflect that students choose courses to study for various reasons which course instructors need to be aware of and understand in order to make courses more responsive to studentteachers' educational needs.

Table 3.14: Lessons learnt from the teaching practice

\begin{tabular}{|l|l|}
\hline Frequency & Learning experience \\
\hline 2 & Teaching is not easy. It can be frustrating. \\
\hline 1 & Learners are not clean slates. The student-teacher's perception about learners was wrong. \\
\hline 1 & One should always be prepared. \\
\hline 1 & Student behaviour and the course for that particular behaviour. \\
\hline 2 & Importance of mentor teachers. \\
\hline 4 & Interpersonal skills \\
\hline 1 & Knowledge is not equivalent to practice. \\
\hline 3 & Teaching a foreign language need teachers who do a lot of research. \\
\hline 1 & Professional conduct. \\
\hline 1 & Teaching profession need patience and commitment. \\
\hline
\end{tabular}

There are a number of lessons learnt from the teaching practice which include the following; the interpersonal skills; professional conduct; importance of mentoring; teaching are not easy and it can be frustrating. On the similar note, one student-teacher indicated that learners are not clean slates, which highlight that this particular respondent went to the French class with the preconceived idea that learners come to class empty. Moreover, one other respondent states that knowledge is not equivalent to practice whereas the same number of respondents highlighted that they have gained experience in teaching the subject and that teaching profession requires patience and commitment. Responses reflected above show that integrating student teachers' experience from teaching practice contribute to the enhancement of the quality of the course on Curriculum and Teaching of French language because participants have gained new insights which can be applied in teacher training courses such as the one under study.

Table 3.15: Ways in which the teaching practice could be improved

\begin{tabular}{|l|l|}
\hline Frequency & Improvement measures \\
\hline 16 & Teaching practice should be extended to six months or more. \\
\hline 1 & Prior practice could help good practice. \\
\hline 1 & There should be no lesson plans \\
\hline
\end{tabular}

\section{Conclusion and recommendations}

Few students who pursued the program on Curriculum and Teaching of French language objectively reflected on their teaching practice experience. Few opted for learner centred teaching methods which enhanced the interaction in class. Judging from their small figure, the study indicates that the majority go through the teaching practice merely to meet the program requirements instead of sharpening the pedagogical skills imparted to them theoretically. This says that the course instructor and coordinators have a long way to go in order to instil in the student-teachers the love and passion for their chosen courses.

As part of quality enhancement, it is recommended that course instructors should also include components of motivation and life skills in their lectures in order to stimulate and broaden student-teachers 'minds in their respective learning areas. In this regard, this approach would make programs even more meaningful to students who have enrolled for them as they would be able to devise motivational strategies in order to rectify the counter foreign language attitude of learners which most experienced.

Moreover, student-teachers should not implement the pre-conceived ideas such as learners who are beginners in foreign language learning could not understand instruction given in a target language; in this case French language as this has adverse results on the quality of the teaching and learning of French as a foreign language. In addition, experiential learning in the form of annual school visits in which students taking the course on Curriculum and Teaching of French observe in service teachers when teaching French language in their respective schools is highly recommended. This would have a significant motivational factor while also making students teacher to be more reflective about the socio-cultural interface that only manifests to studentteachers during the teaching practice.

Student teachers should be advised to use different methods interchangeably in order to ensure the efficient exploration of various methods of teaching French as a foreign language. This is recommended because the study reveals that a number of student-teacher specializing in French language had the difficulty applying various teaching methods that they were taught. This is evident from the results because the majority relied mostly on the traditional teaching method which basically put emphasis on the use of the learners' maternal 
language at the expense of the target language. This does not only end here because it gives impetus to the question of bridging the gap between theory and practice.

There should be a fixed duration for the internship program so that teacher-trainees know the exact time for the exercise. This would create uniformity for all students and it will also cater for various schools' administrative and academic activities such as time -table, budget for school trips etcetera. This means if the duration is three months and school $\mathrm{X}$ opens earlier than school Y, students who started earlier should finish at the time stipulated under the teaching practice regulations as this gives them an added advantage of practice particularly as the majority of participants felt that the duration is very brief.

\section{References}

Bukaliya, R. (2012). "The potential benefits and challenges of internship programs in an ODL institution: A case for the Zimbabwe Open University.” International Journal in New Trends in Education and Their Implications. Vol 3, Issue 1.

Chennat, S. (2014). "Internship in pre-service teacher Education program: A global Perspective". IMPACT JOURNALS. Vol 2, Issue 11

Heeralal, P.J., Bayaga, A. (2011). "Pre-service Teachers' experiences of Teaching Practice: Case of South African University" Journal of Social Science, Vol 28 (2)

Hénard, F. Roseveare, D. (2012). Fostering Quality Teaching in Higher Education: Policies and Practices. OECD.

Kagoda, A.M, Itagaagar, N. (2013) Ä survey of Teacher Trainees’ Expectations, experiences and Assessment in Uganda" Journal of Educational and Social Research. Vol 3 (5).

Kiggundu,E. Nayimuli,S. (2009) Teaching practice: a make or a break phase for student-teachers. South African Journal of Education. Vol 29 pp 345-358.

Komba,S.C., Kira, E.S. (2013) "The effectiveness of Teaching Practice in Improving Student Teachers' Teaching Skills in Tanzania" Journal of Education and Practice. Vol 4 No 1.

Jain, P., Parihar, K.S. (2017). "Study of effects of pre teaching training experience on student teachers" International Journal of Research. Vol 5, issue 10 pp 59-62

Monyatsi, P. (2004) "A proposal to establish a Teacher Pilot Mentoring Scheme (TPMS) for pre-service teachers in Botswana-The case of the University of Botswana". Education Research and Knowledge Systems. Swaziland Educational Research Association. Swaziland.

Ondigi, S.R (2011). "Globalisation of University programmes and Community linkages: A Case of Two Kenyan Universities". Centre for Promoting Ideas, USA www.ijhssnet.com

Parveeen, S. (2012). "Internship Program in Education: Effectiveness, Problems and Prospects". International Journal of Learning \& Development. Vol 2, No1. Pp 487-498.

Raising,M. Ericssin, J.G. Abdulovic, T. (2011). Theoretical Quality Management Frameworks in Today's Business: An Automobile Industry Application. Proceedings of Informing Science \& IT Education Conference (INSITE)

Raselimo, M. (2013). “Accreditation Standards for Higher education in Lesotho: Exploring issues of quality and relevance" Lesotho Social Science Review: Special Issue on Higher Education. ISSN 1028-0790.

Saunders, M., Lewis, P., and Thornhill, A. (2016). Research Methods for Business Students seventh (ed), Pearson, London.

Zhang, S. (2010). "Analysis on the concepts and Theories of the Quality of Graduate Education”. Asian Social Sciences. Vol 6, No 12 